\title{
Pengujian Level Kreativitas Pada Siswa Berdasarkan Skala Kekuatan dan Kebajikan Karakter dan Tes Kreativitas Verbal
}

\author{
Zulmi Ramdani ${ }^{* 1}$, Bagus Hary Prakoso², Silmi Amrullah ${ }^{3}$,Lidwina Felisima Tae ${ }^{4}$, Feri Indra \\ Irawan $^{5}$ \\ 1,5 Fakultas Psikologi Universitas Islam Negeri (UIN) Sunan Gunung Djati Bandung \\ ${ }^{2}$ Puspendik-Balitbang, Kementrian Pendidikan dan Kebudayaan Republik Indonesia \\ ${ }^{3}$ Universitas Pendidikan Indonesia (UPI) Bandung \\ ${ }^{4}$ Universitas Timor Kupang Nusa Tenggara Timur \\ e-mail : *zulmiramdani@uinsgd.ac.id
}

\begin{abstract}
Creativity is an important aspect in building a good culture of education. Good creativity is shown by the learning outcomes that not only focus on improving cognitive abilities but also on the process of solving a problem either by using divergent or convergent thinking skills. This study was carried out with descriptive quantitative. The study was conducted using two instruments, namely the creativity character scale consisting of 10 items and a set of Verbal Creativity Tests (TKV) consisting of six subtests. The total subjects involved in this study were 470 students who were divided into groups that got the character scale of creativity with the group given the verbal ability test. The results of the study, either through the creativity character scale or verbal creativity tests, show the acquisition of creativity scores which describes that there are still many individuals who have not been optimized in terms of creativity. This becomes a serious concern that can be anticipated by providing information about the importance of creativity. It is also built by creating an instrument that is more effective directly capturing the condition of one's creativity as a whole.
\end{abstract}

Keywords: Creativity, Creativity Scale, Verbal Creativity Test

\begin{abstract}
Abstrak. Kreativitas adalah aspek yang penting dalam membangun budaya pendidikan yang baik. Kreativitas yang baik ditunjukkan dengan hasil pembelajaran yang tidak hanya berfokus pada peningkatan kemampuan kognitif tetapi juga pada proses penyelesaian masalah baik menggunakan kemampuan berpikir divergen ataupun konvergen. Studi ini menggunakan pendekatan kuantitatif deskriptif. Penelitian dilakukan dengan menggunakan dua instrumen yaitu skala karakteristik kreatif dan tes kreativitas verbal (TKV) yang terdiri dari enam subtes. Total partisipan yang terlibat adalah sekitar 470 siswa yang dibagi ke dalam dua kelompok dimana kelompok pertama mendapatkan skala kreatif dan kelompok lainnya diberikan tes kreativitas verbal. Hasil penelitian menunjukan bahwa dengan menggunakan kedua instrumen tersebut masih banyak individu yang memperoleh skor tidak maksimal. Ini menjadi perhatian serius yang harus diantisipasi dengan menyediakan informasi tentang pentingnya kreativitas dalam kehidupan. Ini juga dapat dibangun dengan menciptakan instrumen yang lebih efektif dimana mampu mengukur secara langsung kondisi kreativitas seseorang secara holsitik.
\end{abstract}

Kata kunci: Kreativitas, Skala Kreativitas,Tes Kreativitas Verbal

Kemajuan dan perkembangan teknologi saat ini, mengharuskan individu untuk mampu menyesuaikan diri mereka dengan perubahan tersebut dalam seluruh aspek 
kehidupan tidak terkecuali dalam konteks pendidikan (Hromcová \& Agnese, 2018). Pendidikan yang adaptif adalah suatu sistem yang mampu mengkolaborasikan berbagai aspek dalam pendidikan dengan perkembangan dan penggunaan teknologi terkini (Hromcová \& Agnese, 2018). Salah satu tantangan yang dihadapi berkaitan dengan perkembangan teknologi tersebut adalah sejauhmana individu mampu mengembangkan potensi dan karakter sesuai dengan tuntutan dunia saat ini. Aspek yang disinyalir penting dalam hal ini adalah mengenai aspek kreativitas. Kreativitas ini dianggap sesuatu yang sangat dibutuhkan terutama di era teknologi yang semakin canggih ini (Runco, 2018). Melalui aspek kreativitas individu belajar bagaimana mereka mengenail dunia lebih obyektif dan dinamis sehingga membuat organisasi pikiran dan kepribadiannya menjadi lebih sehat (Tian et al., 2018).

Permasalahan kreativitas sudah banyak dibahas dalam beberapa penelitian terdahulu, dimana aspek ini ditempatkan pada konteks yang serius terutama ketika ingin mengembangkan kesuksesan berdasarkan personal elemen di dalam sekolah (Revilla \& Rodríguez-Prado, 2018). Kreativitas adalah tanggungjawab bersama, dimana setiap elemen dalam pendidikan haruslah secara positif dan aktif untuk menciptakan suasana pembelajaran dan pendidikan yang berbasis pada kekuatan kreativitas (Ramdani \& Fahmi, 2014). Kreativitas juga adalah indikator bahwa individu sekarang secara efektif mampu mengkolaborasikan pengetahuan dan nalar tertinggi mereka dalam bekerja (Delis et al., 2007). Dewasa ini juga penggunaan karak- ter kreativitas ini diperlukan untuk melakukan adaptasi terhadap perkembangan globalisasi yang menuntut kita untuk terus berpikir kreatif (Hromcová \& Agnese, 2018).

Kreativitas adalah sesuatu yang sangat kompleks, mempunyai banyak domain, dan muncul dalam beragam kehidupan manusia (Lucas, 2016). Aspek ini dianggap sebagai kemampuan intelektual manusia yang paling tinggi karena bersifat original dan unik. (Abdulla \& Cramond, 2017). Kemampuan kreativitas ini juga digunakan sebagai landasan dasar yang berarah pada divergent thingking dan problem solving (Abdulla \& Cramond, 2017). Aspek ini juga berkaitan langsung dengan kemampuan individu dalam menghasilkan suatu performa belajar (Zhou, Shen, Wang, Neber, \& Johji, 2013).

Dalam konteks pendidikan, kreativitas berfungsi untuk mengembangkan potensi dan keberadaan peserta didik yang diharapkan mampu mengoptimalkan kemampuan yang mereka miliki (Konstantinidou, Zisi, Katsarou, \& Michalopoulou, 2015). Guru dan murid akan sama-sama menyadari apa yang seharusnya mereka lakukan, dimana guru mengganggap murid sebagai seseorang pembelajar aktif dan murid mengganggap kreativitas ini adalah materi positif yang harus mereka kembangkan dengan baik (Lucas, 2016). Selain itu juga keberaadan kepala sekolah ataupun elemen akademik lainnya dalam sekolah akan menjadi pelengkap di dalam mengembangkan sekolah yang berbasis pada kreativitas (Ramdani, 2018b). 
Pada kenyataanya, tidak semua aspek dalam pendidikan tersebut menyadari akan pentingnya karakter kreativitas ini (Ramdani, 2018b). Studi awal penelitian mengungkapkan bahwa tidak semua elemen mengganggap bahwa kreativitas itu penting, mereka cenderung menilai bahwa yang harus paling kreatif itu adalah peserta didik (Ramdani, 2018b). Tetapi ketika kreativitas itu akan dijadikan sebagai faktor yang penting dalam kehidupan mereka, maka kolaborasi di antara elemen-elemen tersebutlah yang sangat penting (Ramdani, 2018b).

Banyak penelitian sebelumnya yang sudah mencoba melakukan pengukuran kreativitas dalam berbagai konteks, diantaranya adalah melakukan studi sistematika dan metanalisis terhadap pengalaman kreativitas individu di sekolah yang dikemudian dikembangkan dalam bentuk indikator yang akan menjadi skala pengukuran kreativitas (Ma, Yang, Wang, \& Zang, 2018). Ada juga yang menguji kreativitas dengan menyajikan seperangkat persoalan semantis melalui persoalan kata dan pilihan diksi yang menjadi bahan penilaian kreativitas (Georgiev \& Georgiev, 2018). Kenett (2018) juga menjelaskan melalui pengukuran semantik bahasa yang ditujukan menguji ide kreativitas. Namun di Indonesia sendiri masih jarang sekali ditemukan sebuah evaluasi atau pengukuran yang mencoba mengkolaborasikan pendekatan skala dengan pengujian kemampuan secara langsung. Penelitian ini dilakukan untuk mengetahui bagaimana kondisi level kreativitas yang saat ini ada di sekolah menengah pertama dan sekolah menengah atas yang ada di beberapa wilayah di Indonesia. Studi dilakukan dengan menyajikan seperangkat instrumen yang tervalidasi sehingga menjadi alat yang baik dalam mengetahui kondisi kreativitas tersebut.

\section{Metode}

\section{Pendekatan Penelitian}

Studi ini dilakukan untuk menguji dan melihat seperti gambaran kreativitas pada siswa sekolah menengah atas di berbagai sekolah. Desain penelitian kuantitatif yang digunakan adalah statistika deskriptif dan inferensial yang menghasilkan gambaran kriteria dan level kreativitas yang ada pada subjek penelitian (Heng, Wagner, Barnes, \& Guarana, 2018).

\section{Prosedur Penelitian}

Sampel dalam penelitian ini diambil dengan menggunakan purposive sampling dengan mempertimbangkan subjek berdasarkan kebutuhan penelitian. Studi ini dilakukan untuk melihat bagaimana kondisi kreativitas siswa di sekolah. Ada dua tahapan yang dilakukan dalam penelitian ini. Tahapan pertama adalah dengan melakukan uji statistika deskriptif dengan menggunakan Skala Kekuatan dan Kebajikan Karakter yang dikembangkan oleh Peterson dan Seligman pada tahun 2004 (Ramdani \& Fahmi, 2014). Sedangkan tahapan yang kedua adalah menguji kemampuan kreativitas verbal atau Tes Kreativitas Verbal yang dikembangkan oleh Tim Fakultas Psikologi UI (LPSP3 UI, 2011).

\section{Instrumen}

Instrumen yang digunakan dalam penelitian ini terdiri dari dua bentuk, 
pertama menggunakan Skala Kekuatan dan Kebajikan Karakter yang terdiri dari 10 aitem yang bergerak dari skor 1 sampai 5 dengan bentuk penilaian menggunakan skala likert. Sedangkan instrumen yang kedua adalah Tes Kreativitas Verbal yang terdiri dari enam subtes yaitu subtes permulaan kata, menyusun kata, membentuk kalimat tiga kata, sifat-sifat yang sama, macam penggunaan, dan apa akibatnya.

\section{Partisipan}

Pengambilan data dilakukan dengan menyebarkan skala dan mengujikan seperangkat tes kepada kurang lebih 470 siswa usia 12 sampai 18 tahun.

\section{Hasil}

\section{Hasil Skala Kekuatan dan Kebajikan} Karakter

Penelitian pertama dilakukan dengan menyebarkan data Skala Kekuatan dan Kebajikan Karakter di berbagai sekolah yang telah ditentukan sebelumnya sesuai dengan kebutuhan peneliti. Pengisian skala ini kurang lebih menghabiskan waktu 5 menit untuk setiap subjek. Tahapan ini dilakukan dengan secara klasikal di dalam kelas karena alasan efektivitas dan efisiensi.

Subyek pada tahapan pertama ini adalah sebanyak 278 subyek yang terdiri dari 105 orang laik-laki dan 173 perempuan. Informasi dari data disampaikan bahwa subyek perempuan lebih banyak dibandingkan laki-laki dalam penelitian ini.

Deskripsi pada tabel 2, usia menjelaskan rentang usia subyek dalam penelitian ini. Siswa usia 16 sampai 17 tahun menjadi subyek yang paling banyak terlibat dalam penelitian sedangkan siswa usia 18 sampai 19 tahun merupakan yang paling sedikit terlibat dalam penelitian. Persentase untuk masing usia yang paling besar adalah 60,4 \% dan yang paling kecil hanya sebara 6,9 \%. Skor karakter kreativitas pada tahapan ini dikategorisasikan menjadi mereka individu yang mempunyai kreativitas tinggi dan mereka yang mempunyai kreativitas rendah. Pembagian dua kategori kelompok ini didasarkan pada nilai mean atau rata-rata yang dijadikan sebagai norma dalam menentukan tinggi atau rendahnya kreativitas (Ramdani, 2018). Mereka yang tinggi berarti mempunyai nilai total yang lebih dari rata-rata (total skor diperoleh dari 10 aitem yang dijumlahkan), sedangkan yang rendah dibawah rata-rata.

Tabel 1

Deskripsi Subyek Berdasarkan Jenis Kelamin

\begin{tabular}{|c|c|c|c|c|}
\hline & \multicolumn{2}{|c|}{$\begin{array}{c}\text { Skala } \\
\text { Kreativitas }\end{array}$} & \multicolumn{2}{|c|}{$\begin{array}{c}\text { Tes Kreativitas } \\
\text { Verbal }\end{array}$} \\
\hline & $\begin{array}{c}\text { Freku } \\
\text { ensi }\end{array}$ & $\begin{array}{c}\text { Persen } \\
\text { tase }\end{array}$ & $\begin{array}{c}\text { Freku } \\
\text { ensi }\end{array}$ & $\begin{array}{c}\text { Persen } \\
\text { tase }\end{array}$ \\
\hline $\begin{array}{l}\text { Laki- } \\
\text { Laki }\end{array}$ & 105 & $37,8 \%$ & 79 & $41,1 \%$ \\
\hline $\begin{array}{l}\text { Peremp } \\
\text { uan }\end{array}$ & 173 & $62,2 \%$ & 113 & $58,9 \%$ \\
\hline Total & 278 & $100 \%$ & 192 & $100 \%$ \\
\hline
\end{tabular}

Tabel 2

Deskripsi Subyek Pada Skala Kreativitas

Berdasarkan Usia

\begin{tabular}{ccc}
\hline & \multicolumn{2}{c}{ Usia } \\
\cline { 2 - 3 } & Frekuensi & Persentase \\
\hline $11-13$ tahun & 28 & $10,1 \%$ \\
14-15 tahun & 63 & $22,6 \%$ \\
$16-17$ tahun & 168 & $60,4 \%$ \\
$18-19$ tahun & 19 & $6,9 \%$ \\
Total & 278 & $100 \%$ \\
\hline
\end{tabular}


Deskripsi pada tabel 2, usia menjelaskan rentang usia subyek dalam penelitian ini. Siswa usia 16 sampai 17 tahun menjadi subyek yang paling banyak terlibat dalam penelitian sedangkan siswa usia 18 sampai 19 tahun merupakan yang paling sedikit terlibat dalam penelitian. Persentase untuk masing usia yang paling besar adalah $60,4 \%$ dan yang paling kecil hanya sebara 6,9\%. Skor karakter kreativitas pada tahapan ini dikategorisasikan menjadi mereka individu yang mempunyai kreativitas tinggi dan mereka yang mempunyai kreativitas rendah. Pembagian dua kategori kelompok ini didasarkan pada nilai mean atau rata-rata yang dijadikan sebagai norma dalam menentukan tinggi atau rendahnya kreativitas (Ramdani, 2018). Mereka yang tinggi berarti mempunyai nilai total yang lebih dari rata-rata (total skor diperoleh dari 10 aitem yang dijumlahkan), sedangkan yang rendah dibawah rata-rata.

Tabel 3

Kategori Karakter Kreativitas

\begin{tabular}{lcc}
\hline & \multicolumn{2}{c}{ Level Kreativitas } \\
\cline { 2 - 3 } & Frekuensi & $(\%)$ \\
\hline Kreativitas & 128 & 46 \\
Tinggi & & \\
$\begin{array}{l}\text { Kreativitas } \\
\text { Rendah }\end{array}$ & 150 & 54 \\
Total & 278 & 100 \\
\hline
\end{tabular}

Informasi yang diperoleh dari tabel 3 menggambarkan bahwa dalam penelitian tahap 1 ini yang mempunyai karakter kreativitas pada kategori rendah dibandingkan dengan mereka yang mempunyai kategori tinggi.

\section{Hasil Tes Kreativitas Verbal}

Tahapan kedua ini dilakukan dengan menyajikan seperangkat tes yang mengukur kecerdasan verbal remaja dengan proses administrasi kurang lebih 60 menit untuk menyelesaikan semua subtes. Tes dilakukan secara klasikal karena sangat memudahkan dalam proses administrasinya dan efektif serta efisien baik secara waktu ataupun biaya(Marques-Costa, Almiro, \& Simões, 2018). Subyek pada tahapan kedua adalah sebanyak 192 subyek yang terdiri dari 79 orang laik-laki dan 113 perempuan. Informasi dari data disampaikan bahwa subyek perempuan lebih banyak dibandingkan laki-laki dalam penelitian ini.

Tabel 4

Deskripsi Berdasarkan Usia

\begin{tabular}{lcc}
\hline & \multicolumn{2}{c}{ Usia } \\
\cline { 2 - 3 } & Frekuensi & Persentase \\
\hline $15-16$ & 146 & $76 \%$ \\
tahun & & \\
$17-18$ & 46 & $24 \%$ \\
tahun & & \\
Total & 192 & $100 \%$ \\
\hline
\end{tabular}

Deskripsi pada tabel usia menjelaskan rentang usia subyek dalam penelitian ini. Remaja usia 15 sampai 16 tahun menjadi yang paling banyak menjadi subyek dengan total persentase sebesar $76 \%$, sedangkan remaja usia 17 sampai 18 tahun sebesar $24 \%$. Untuk penentuan level kreativitas dalam penelitian ini didasarkan pada kecerdasan kreativitas atau CQ (Creative Quotient) yang sudah dinormakan sesuai rentang usia 10 hingga 18 tahun (Munandar et al., 1985). 
Tabel 5

Kategori Kecerdasan Kreativitas

\begin{tabular}{lcc}
\hline & \multicolumn{2}{c}{ CQ } \\
\cline { 2 - 3 } & Frekuensi & $\%$ \\
\hline Dibawah rata-rata & 7 & 3,6 \\
Rata-rata & 59 & 30,7 \\
Diatas rata-rata & 56 & 29,2 \\
Superior & 39 & 20,3 \\
Sangat Superior & 31 & 16,1 \\
Total & 192 & 100 \\
\hline
\end{tabular}

Note. CQ = Creativity Quotient

Dari Tabel 5 di atas dapat digambarkan bahwa dalam penelitian ini mayoritas subyek berada pada kategori rata-rata yaitu dengan persentase sebanyak 30,7\%. Kemudian disusul dengan kategori diatas ratarata $(29,2 \%)$, superior $(20,3 \%)$, sangat superior $(16,1 \%)$, dan yang terakhir adalah dibawah rata-rata yaitu sebesar $3,6 \%$.

\section{Diskusi}

Kreativitas sebagai bagian terpenting dalam diri seorang individu, mengharuskan individu tersebut telebih dahulu paham dan sadar akan kemampuannya ini (Burns, Zhang, Wieth, \& Touyz, 2017). Karena pada hakikatnya adalah setiap orang mempunyai karakter ini tetapi yang menjadi pembedanya adalah apakah individu tersebut mengetahuinya atau tidak. Dalam pengukurannya kreativitas ini hadir dalam berbagai konteks dan bentuk sehingga diperlukan pemahaman yang mendasar mengenai kontruk kreativitas (Glăveanu, 2018). Ketika seorang individu memulai bekerja dan beraktivitas menggunakan kemampuan kreativitasnya, di saat seperti itulah dia sedang mengembangkan potensi kecerdasannya yang berupa berpikir divergen yaitu cara berpikir dengan menyediakan banyak alternatif dan solusi terhadap apa yang akan dilakukan (Japardi, Bookheimer, Knudsen, Ghahremani, \& Bilder, 2018). Kreativitas ini tidak terlepaskan dari cara berpikir divergen yang selalu menghadirkan variasi dari pemecahan masalah yang akan digunakan. Sehingga dengan kemampuan ini diharapkan setiap individu mampu menunjukan eksistensinya dalam bekerja dan beraktivitas (Japardi et al., 2018).

Kreativitas sendiri walaupun tidak menjadi satu-satunya yang menentukan keberhasilan seorang anak dalam pembelajarannya, setidaknya ini menjadi langkah awal untuk mengembangkan kemampuan intelektualnya (Zabelina \& Ganis, 2018). Aspek ini sangat erat kaitannya dengan performa yang akan ditunjukan oleh anak di sekolah tetapi tidak menjadi satusatunya yang signifikan, sehingga perlu diberikan pelatihan supaya kecakapan dalam berpikir dan bekerja bisa secara optimal dilakukan (An, Song, \& Carr, 2016). Kemampuan ini harus disadari juga sebagai bentukan lingkungan dan potensi kecerdasan yang telah individu bawa dari genetiknya, sehingga yang harus dilakukan selanjutnya adalah mengoptimalisasikannya (Japardi et al., 2018). Hasil penelitian mengenai Skala Karakter Kreativitas menunjukan bahwa pada subyek penelitian ini belum secara menyeluruh diperoleh hasil yang memuaskan, artinya masih ada kelemahan yang terjadi berkenaan dengan potensi dan persepsi individu terhadap kreativitasnya.

Perolehan subyek yang dikategorikan kreativitas rendah lebih banyak dibanding 
yang tinggi juga dikarenakan beberapa kondisi yang memang secara demografi itu sangat berpengaruh terhadap konsistensi kecerdasan yang mereka bangun. Subyek dalam penelitian ini diambil secara random di daearah pedesaan, yang ketika dilakukan pemetaan dan studi awal mereka kesulitan dalam memahami dan mengungkapkan apa yang dimaksud dengan kreativitas. Hal ini terjadi karena perbedaan lingkungan dimana mereka tinggal tidak begitu memperhatikan potensi kreativitasnya. Pertama, secara genetik potensi kreativitas itu diperoleh karena kontribusi kecerdasan seorang individu sejak lahir (de Manzano \& Ullén, 2018). Kedua, potensi kecerdasan itu bisa dikembangkan karena pengaruh dimana dia tinggal dan bagaimana dia berinteraksi dengan lingkungan yang menuntutnya untuk melakukan aktivitas kreatif (Hur, Jeong, \& Piffer, 2014). Kontribusi yang signifikan terjadi memang karena kecerdasan bawaan, tetapi yang paling penting adalah bagaimana dia berinteraksi dengan lingkungannya sehingga segala bentuk aktivitas dan kegiatannya bisa dikerjakan menggunakan kreativitas sebagai proses berpikir divergennya (Hur et al., 2014).

Pada kasus subyek penelitian ini, dominasi subyek yang terlibat adalah mereka yang berinteraksi dengan situasi dan iklim sekolah yang kurang aktif dalam hal kreativitas, sehingga tidak memunculkan suatu perasaan mengikat terhadap potensinya tersebut. Secara sistematis, kolaborasi antara elemen sekolah bisa dilakukan untuk meningkatkan kreativitas pada peserta didik mereka (Ramdani, 2018). Jenjang sekolah dari mulai mereka anak- anak sampai usia remaja harus secara konsisten dipenuhi dengan iklim yang kreatif karena hal tersebut dapat membantu mempertahankan potensi kreativitas pada anak (Gajda, 2016). Peran kepala sekolah sangat efektif ketika menciptakan suatu sistem dan iklim belajar yang kreatif yang didasarkan pada potensi anak sehingga bisa mengembangkan dan menyediakan fasilitas yang berkaitan dengan aspek-aspek kreativitas pada anak (Y. S. Chang, Lin, Chien, \& Yen, 2018). Kemudian posisi seorang guru juga begitu penting dalam membangun kreativitas pada anak. Mereka bisa mengajarkan anak hal-hal atau kegiatan yang kreatif didasarkan pada perkembangan teknologi yang semakin maju dan menggunakan fasilitas internet sebagai media mengembangkan kreativitasnya (Boysen, 2017). Guru juga bisa menstimulasi suasana pembelajaran menjadi iklim yang menyenangkan atau memberikan penghargaan kepada hasil kreativitas anak sehingga mereka secara langsung termotivasi untuk terus mengembangkan kreativitasnya tersebut (S. H. Chang, Wang, \& Lee, 2016).

Studi kedua yang dilakukan dalam penelitian ini juga menunjukan masih adanya titik lemah dalam pengembangan kreativitas anak di sekolah. Walaupun dalam hasil penelitian tunjukan memang dominasi kecerdasan kreativitas anak di atas rata-rata, dari segi jumlah masih banyak anak yang memperoleh skor kreativitas dibawah rata-rata. Hal tersebut juga harus menjadikan perhatian lainnya berkaitan dengan kemampuan verbal atau kreativitas verbal anak-anak. 
Tes kreativitas verbal sangat berguna dalam memberikan kesempatan kepada anak untuk mengekspesikan ide-ide mereka yang berfokus pada proses berpikir divergent (Munandar et al., 1985). Sama halnya dengan karakter kreativitas yang merupakan bagian dari kekuatan individu, tes kreativitas verbal ini juga menuntut individu atas potensi kecerdasan mereka yang lebih besar kaitannya dengan periode atau masa otak yang sehat dalam tubuh mereka (Fink et al., 2014). Seseorang yang mempunyai kecakapan secara verbal, mereka dibekali dengan sistem berpikir dan kondisi otak beserta seluruhan cairan gray matter didalamnya yang bagus dan memang sudah terjadi ketika proses kehamilan (Fink et al., 2014). Hal ini tentunya sangat berkaitan erat dengan kondisi seorang ibu ketika hamil atau ketika memberikan asupan nutrisi dan gizi kepada anak-anak mereka (Tarnoto \& Purnamasari, 2009). Skor kreativitas verbal yang diperoleh subyek perempuan dalam hal ini juga terdapat perbedaan dengan subyek laki-laki, dimana penelitianpenelitian terdahulu juga mengatakan peran jenis kelamin sangat berpengaruh terhadap kecakapan atau kreativitas verbal seorang anak (Fink \& Neubauer, 2006).

Pengujian tahapan kedua sangat terpengaruh oleh banyak bias dalam pelaksanannya, terutama berkaitan dengan kondisi subyek penelitian dalam hal ini dan juga tester yang bertugas dalam proses skoring (Murphy \& Davidshofer, 1997). Bias-bias tersebut mungkin saja berkontribusi terhadap kesalahan skoring atau optimalisasi subyek yang mengerjakan. Pada pelaksanannya karena kesulitan untuk menyesuaikan dengan waktu subyek yang begitu pada karena merupakan program sekolah, sehingga hal ini membuat peneliti meminta kesediaan subyek untuk mengerjakan secara klasikal dengan kondisi performa yang tidak terlalu fit karena sebagian dilaksanakan sesudah program belajar di sekolah selesai. Kondisi tersebut mungkin sangat berpengaruh terhadap kondisi fit dan performa yang ditunjukan oleh subyek ketika mengerjakan tes (Cecil \& $\mathrm{Ph}$, 1981). Masalah lain yang dihadapi ketika dilakukan pengetesan adalah kondisi tester dan skorer yang berkontribusi terhadap penetuan kategori kecerdasan yang diperoleh oleh subyek. Penguji yang tidak kompeten, masalah pribadi yang membuatnya tidak konsentrasi, ataupun masalah-masalah lain yang secara personal berpengaruh terhadap pelaksanaan tes juga bisa berkontribusi terhadap eror pengukuran dalam pengujian kedua ini (Spies \& Plake, 2005).

\section{Kesimpulan}

Penelitian ini menyajikan sebuah sampel gambaran mengenai kreativitas yang saat ini dimiliki oleh peserta didik. Secara umum kreativitas masih menjadi hal yang harus diperhatikan serius mengingat hasil yang diperoleh menunjukan belum munculnya optimalisasi kemampuan dan karakter kreativitas dalam penelitian. Harapan kedepannya penelitian ini akan dikembangkan pada subyek yang lebih banyak sehingga mencakup seluruh Indonesia serta akan menggunakan pendekatan IRT (Item Respon Theory) dalam pengujian dan perhitungannya. 


\section{Daftar Pustaka}

Abdulla, A. M., \& Cramond, B. (2017). After six decades of systematic study of creativity: What do teachers need to know about what it is and how it is measured? Roeper Review, 39(1), 9-23. https://doi.org/10.1080/02783193.2016. 1247398

An, D., Song, Y., \& Carr, M. (2016). A comparison of two models of creativity: Divergent thinking and creative expert performance. Personality and Individual Differences, 90, 78-84. https://doi.org/10.1016/j.paid.2015.10.0 40

Boysen, M. S. W. (2017). Embracing the network: A study of distributed creativity in a school setting. Thinking Skills and Creativity, 26, 102-112. https://doi.org/10.1016/j.tsc.2017.10.00 2

Burns, B. D., Zhang, Y., Wieth, M., \& Touyz, S. (2017). An exploratory study of creativity and eating disorders. Journal of Eating Disorders, 5(1), 536556. https://doi.org/10.1186/s40337017-0176-9

Cecil, R., \& Ph, D. (1981). Test Bias : in God We Trust; The Journal of Special Education, 17(3).

Chang, S. H., Wang, C. L., \& Lee, J. C. (2016). Do award-winning experiences benefit students' creative self-efficacy and creativity? The moderated mediation effects of perceived school support for creativity. Learning and Individual Differences, 51, 291-298. https://doi.org/10.1016/j.lindif.2016.09.
011

Chang, Y. S., Lin, H. C., Chien, Y. H., \& Yen, W. H. (2018). Effects of creative components and creative behavior on design creativity. Thinking Skills and Creativity, 29, 23-31. https://doi.org/10.1016/j.tsc.2018.05.00 7

de Manzano, Ö., \& Ullén, F. (2018). Genetic and environmental influences on the phenotypic associations between intelligence, personality, and creative achievement in the arts and sciences. Intelligence, 69(February), 123-133. https://doi.org/10.1016/j.intell.2018.05. 004

Delis, D. C., Lansing, A., Houston, W. S., Wetter, S., Han, S. D., Jacobson, M., ... Kramer, J. (2007). Creativity lost: The importance of testing higher-level executive functions in school-age children and adolescents. Journal of Psychoeducational Assessment, 25(1), 29-40.

https://doi.org/10.1177/0734282906292 403

Fink, A., Koschutnig, K., Hutterer, L., Steiner, E., Benedek, M., Weber, B., ... Weiss, E. M. (2014). Gray matter density in relation to different facets of verbal creativity. Brain Structure and Function, 219(4), 1263-1269. https://doi.org/10.1007/s00429-0130564-0

Fink, A., \& Neubauer, A. C. (2006). EEG alpha oscillations during the performance of verbal creativity tasks: Differential effects of sex and verbal intelligence. International Journal of Psychophysiology, 62(1), 46-53. 
https://doi.org/10.1016/j.ijpsycho.2006. 01.001

Gajda, A. (2016). The relationship and moderators of school achievement and creativity at different educational stages. Thinking Skills and Creativity, 19, 246-259.

https://doi.org/10.1016/j.tsc.2015.12.00 4

Georgiev, G. V., \& Georgiev, D. D. (2018). Enhancing user creativity: Semantic measures for idea generation. Knowledge-Based Systems, 151, 1-15. https://doi.org/10.1016/j.knosys.2018.0 3.016

Glăveanu, V. P. (2018). Educating which creativity? Thinking Skills and Creativity, 27, 25-32. https://doi.org/10.1016/j.tsc.2017.11.00 6

Heng, Y. T., Wagner, D. T., Barnes, C. M., \& Guarana, C. L. (2018). Archival research: Expanding the methodological toolkit in social psychology. Journal of Experimental Social Psychology, 78(August 2017), 1422.

https://doi.org/10.1016/j.jesp.2018.04.0 12

Hromcová, J., \& Agnese, P. (2018). Globalization, welfare, and the attitudes toward higher education. Economic Modelling, (November 2017), $1-15$.

https://doi.org/10.1016/j.econmod.201 8.05.013

Hur, Y. M., Jeong, H. U., \& Piffer, D. (2014). Shared genetic and environmental influences on self-reported creative achievement in art and science.
Personality and Individual Differences, 68 , https://doi.org/10.1016/j.paid.2014.03.0 41

Japardi, K., Bookheimer, S., Knudsen, K., Ghahremani, D. G., \& Bilder, R. M. (2018). Functional magnetic resonance imaging of divergent and convergent thinking in Big-C creativity. Neuropsychologia.

https://doi.org/10.1016/j.neuropsychol ogia.2018.02.017

Kenett, Y. N. (2019). What can quantitative measures of semantic distance tell us about creativity? Current Opinion in Behavioral Sciences, 27, 11-16. https://doi.org/10.1016/j.cobeha.2018.0 8.010

Konstantinidou, E., Zisi, V., Katsarou, D., \& Michalopoulou, M. (2015). Barriers and inhibitors of creativity in physical education. European Psychomotricity Journal, 7, 17-31. Retrieved from http://search.ebscohost.com/login.asp

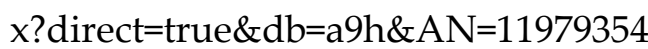
$0 \&$ site $=$ ehost-live $\&$ scope $=$ site

LPSP3 UI. (2011). Buku petunjuk penggunaan tes kreativitas verbal. Depok: Fakultas Psikologi Universitas Indonesia.

Lucas, B. (2016). A five-dimensional model of creativity and its assessment in schools. Applied Measurement in Education, 29(4), 278-290. https://doi.org/10.1080/08957347.2016. 1209206

Ma, X., Yang, Y., Wang, X., \& Zang, Y. (2018). An integrative review: Developing and measuring creativity in nursing. Nurse Education Today (Vol. 62). Elsevier Ltd. 
https://doi.org/10.1016/j.nedt.2017.12.0 11

Marques-Costa, C., Almiro, P. A., \& Simões, M. R. (2018). Computerized cognitive tests (CCT) in elderly: A psychometric review. Revue Europeenne de Psychologie Appliquee, 68(2), 61-68. https://doi.org/10.1016/j.erap.2018.04.0 02

Munandar, S., Achir, Y., Winata, S., Suharso, P., Salim, R., Rifameutia, T., \& Brahma, G. (1985). Laporan penelitian standarisasi tes kreativitas verbal. Jakarta.

Murphy, K. R., \& Davidshofer, C. O. (1997). Psychological Testing: Principles and Applications. Statistics.

Ramdani, Z. (2018a). Construction of academic integrity scale. International Journal of Research Studies in Psychology, 7(1), 87-97. https://doi.org/10.5861/ijrsp.2018.3003

Ramdani, Z. (2018b). Kolaborasi antara kepala sekolah, guru dan siswa dalam menciptakan sistem pendidikan yang berkualitas. In National Conference on Educational Assessment and Plolicy. Jakarta: Balai Pusat Penelitian (Balitbang) Kementrian Pendidikan dan Kebudayaan Republik Indonesia.

Ramdani, Z., \& Fahmi, I. (2014). Profil kekuatan karakter dan kebajikan pada mahasiswa berprestasi. Psympathic, 1, 98-108.

https://doi.org/https://doi.org/10.1557 5/psy.v1i1.471

Revilla, E., \& Rodríguez-Prado, B. (2018). Bulding ambidexterity through creativity mechanisms: Contextual drivers of innovation success. Research
Policy, (January 2017), 0-1. https://doi.org/10.1016/j.respol.2018.05 .009

Runco, M. A. (2018). Creativity. Change: The Magazine of Higher Learning, 39(4), 5560.

https://doi.org/10.3200/CHNG.39.4.55C4

Spies, R., \& Plake, B. (2005). The sixteenth mental measurement yearbook. Nebraska: The University of Nebraska Press.

Tarnoto, N., \& Purnamasari, A. (2009). Perbedaan kreativitas siswa SMPN 2 Moyudan ditinjau dari tingkat pendidikan ibu. Humanitas.

Tian, F., Chen, Q., Zhu, W., Wang, Y., Yang, W., Zhu, X., ... Qiu, J. (2018). The association between visual creativity and cortical thickness in healthy adults. Neuroscience Letters, 683, 104110.

https://doi.org/10.1016/j.neulet.2018.06 .036

Zabelina, D. L., \& Ganis, G. (2018). Creativity and cognitive control: Behavioral and ERP evidence that divergent thinking, but not real-life creative achievement, relates to better cognitive control. Neuropsychologia. https://doi.org/10.1016/j.neuropsychol ogia.2018.02.014

Zhou, J., Shen, J., Wang, X., Neber, H., \& Johji, I. (2013). A cross-cultural comparison: Teachers' conceptualizations of creativity. Creativity Research Journal, 25(3), 239247.

https://doi.org/10.1080/10400419.2012. 730006 